\title{
Libanons store spørgsmål igen i fokus
}

\section{Peter Seeberg}

Den konfessionelle balance, som ligger nedfældet i Libanons forfatning fra 1926 og den nationale pagt fra 1943 er efter årtusindskiftet helt ude af trit med den faktiske virkelighed i Libanon. De negative virkninger af Libanons pluralitet er fastholdt og er vedvarende en kilde til at modvirke national konsensus

Efter attentatet på Rafik Hariri den 14. februar 2005 gik libanesisk indenrigspolitik stort set i stå. I den forstand er der siden indtrådt en slags normalitet. Ikke sådan at forstå, at politikken nu fungerer. Men derved at det igen er de store, principielle spørgsmål, der kendetegner den indenrigspolitiske diskussion $\mathrm{i}$ Libanon: relationerne til Syrien, det palæstinensiske spørgsmål, Hizbollahs rolle og den uafklarede situation omkring den siddende præsident Emile Lahoud.

På trods af at valget foregik for mere end et år siden, er den siddende regering alt andet end handlekraftig, kritikken af den udbredte korruption breder sig igen, og en række væsentlige sociale og økonomiske spørgsmål får lov at ligge. Internationalt er der støtte til synspunktet om at udskifte den libanesiske præsident. Bl.a. har USA ved flere lejligheder markeret, at det ville være en god ting, hvis Libanons præsident repræsenterede landets fremtid, ikke dets fortid, med slet skjult adresse til det hedengangne Syrien-dominerede Libanon, hvor alt blev bestemt fra Damaskus.

Fornyet uro blandt palæstinenserne

I sommeren 2006 har der været kampe i Bekaa-dalen mellem den li- 
banesiske hær og palæstinensiske militser: syrisk støttede Fatah al-Intifada, PFLP-GC m.fl. Grupperingerne er vrede over den libanesiske kampagne for at afvæbne de palæstinensiske grupper i og uden for lejrene og ved flere lejligheder er det kommet til direkte konfrontationer, som truer den relative borgfred, der ellers har været mellem de libanesiske myndigheder og de palæstinensiske militser i Libanon.

Det palæstinensiske spørgsmål i Libanon har rødder helt tilbage til efter etableringen af staten Israel. Hver gang der bliver taget initiativer, der peger i retning af nye aftaler mellem Israel og palæstinenserne, dukker spørgsmålet om de palæstinensiske flygtninges tilstedeværelse i Libanon op i de libanesiske medier. Den enkle årsag er, at Libanon ikke vil løse et problem, som det betragter som Israels. Dette synspunkt er i god overensstemmelse med officielle palæstinensiske og arabiske synspunkter, men har samtidig i hele anden halvdel af det 20. århundrede udgjort en bekvem ideologisk legitimering for en libanesisk praksis, der afskar palæstinenserne mulighed for at blive integreret i det libanesiske samfund.

Sidst der var storpolitisk fokus på spørgsmålet var i sommeren 2000. Det begyndte allerede under Camp David-mødet mellem Barak, Arafat og Clinton, der som bekendt endte resultatløst. Og gennem hele efteråret frem til Clintons exit og valget af Sharon gjorde højtstående libanesiske politikere i taler, politiske kommentarer osv. følgende synspunkt gældende: Der skulle - som en del af en endelig fredsaftale mellem Israel og palæstinenserne - findes en løsning på de palæstinensiske flygtninges tilstedeværelse i Libanon, som respekterede FN's resolution 194 fra 1948: flygtningenes ret til at vende tilbage til deres hjemstavn eller modtage erstatning. Libanon ville ikke acceptere en løsning, der indebar at palæstinenserne blev en del af det libanesiske samfund.

Heller ikke i det nye årtusind så en palæstinensisk stat dagens lys. Snarere blev fredsprocessen i 1990'erne afløst af en kronisk konflikttilstand, der ind i mellem udviklede sig til nærmest krigslignende tilstande. Likud-regeringen skulle finde sine ben i forhold til de fire problemstillinger, der tilsammen rummer de helt afgørende problemer i forholdet mellem Israel og palæstinenserne: spørgsmålet om grænsedragning, de israelske bosættere i de besatte områder, Jerusalems status og spørgsmålet om palæstinensiske flygtninge.

Det palæstinensiske flygtningespørgsmål er en uhyre kompliceret affære, der tilmed er belastet af sin lange historie: gennem mere end 50 år har det hørt til blandt verdens mest omfattende flygtningeproblemer. I Israels nabolande lever adskillige millioner palæstinensiske flygtninge, der næppe nogensinde vil 
kunne vende tilbage til deres hjemstavn.

De palæstinensiske flygtninge udgør en meget stor del af verdens samlede antal flygtninge. Ingen kender det præcise antal, men et gæt på ca. 5 mio. er næppe helt ved siden af. De fleste lever i Mellemøsten, hvor der i december 2005 var registreret 4.349.946 palæstinensiske flygtninge - af UNRWA, United Nations Relief and Works Agency in the Near East, dvs. den FN-organisation, der i 1949 blev etableret specielt med henblik på at tage sig af dette omfattende flygtningeproblem. De palæstinensiske flygtninge er således for de flestes vedkommende uden for UNHCR's auspicier. Den demografiske vækst, der i en årrække lå på niveau med verdens fattigste lande, aftog i slutningen af 1990'erne og denne tendens er fortsat på den anden side af årtusindskiftet.

Af de 4.349.946 flygtninge lever de 1.278 .678 (dvs. 29\%) i lejre, heraf 10 lejre i Jordan, 12 i Libanon, 10 i Syrien, 8 i Gaza og 19 på Vestbredden. Lejrene er vidt forskellige, både med hensyn til størrelse og hvad angår den boligmæssige standard, faciliteter osv. Der er tilsyneladende en nær sammenhæng mellem disse forhold og den position, som er blevet palæstinenserne til del i de lande, som huser dem.

Ifølge UNRWA var der i december 2005404.170 registrerede palæstinensiske flygtninge i Libanon, heraf
213.349 i lejre. De har siden Israels oprettelse i maj 1948 haft en omtumlet tilværelse, præget af eksterne forhold som de kun delvist har haft indflydelse på, modsætninger mellem palæstinensere og libanesere og ind imellem konflikter indbyrdes mellem palæstinensiske grupper. Siden borgerkrigens afslutning har palæstinenserne været udelukket fra de fleste former for beskæftigelse uden for lejrene, ligesom det officielle Libanon på mange måder har forøget adskillelsen mellem den libanesiske befolkning og lejrenes befolkning - kort sagt bidraget til isolation af den palæstinensiske flygtningebefolkning.

På det mere uformelle niveau har der dog været mange eksempler på undtagelser. For det første gennem personlige relationer, herunder ægteskaber, for det andet gennem brud på reglerne, fx i form af ansættelser (selvsagt er noget sådant svært at kontrollere), for det tredje i form af emigration: palæstinensere har som politiske flygtninge forladt $\mathrm{Li}$ banon, især med Europa som destination. Og for det fjerde gennem den naturalisering, der er foregået. En lov fra 1994 gav mulighed for at op mod en kvart million mennesker kunne få libanesisk statsborgerskab. Loven blev effektueret i 1996 og det hævdes uofficielt i Libanon, at ud af de 250.000 nye statsborgere, som for langt de flestes vedkommende var muslimer, var 30-40.000 palæstinensere. 
De palæstinensiske flygtninge er på mange måder paria'er i det libanesiske samfund, for hvilke det er uhyre vanskeligt at bosætte sig uden for lejrene og opnå anerkendelse $\mathrm{i}$ det libanesiske samfund. En naturalisering ville kunne ændre på dette, men der er også blandt menige libanesere stor modstand mod at tillade palæstinensere at opnå libanesiske borgerrettigheder, herunder arbejdstilladelse.

Perspektiverne for de palæstinensiske flygtninge synes således at være dybt problematiske. Hvor der i andre arabiske stater i regionen foregår en integration af de palæstinensiske flygtninge - mest markant i Jordan, men også i Syrien, fastholdes i Libanon en segregation, der kun langsomt forandrer sig. Foruden de nævnte årsager hænger det også sammen med landets størrelse: I Libanon lever ifølge FN-estimater 3,7 mio. libanesere. Derfor ville omkring 400.000 overvejende sunni-muslimske palæstinensere føre til en yderligere skæwhed i det uhyre følsomme konfessionelt baserede system.

De palæstinensiske flygtninge indgår også i det udenrigspolitiske spil mellem Syrien og Israel. Det historiske forhold mellem Israel og Syrien kan beskrives som én lang række spildte muligheder. Den tilsyneladende kroniske modsætning mellem Israel og Syrien stammer helt tilbage fra Israels erobring af Golanhøjderne i junikrigen i 1967, men det var mere end noget andet den permanente krigstilstand under Libanons borgerkrig, der lagde grunden til de konfliktfyldte indbyrdes relationer mellem Israel og Syrien, som har kendetegnet situationen siden borgerkrigen ophørte i 1990.

De palæstinensiske grupper i og uden for flygtningelejrene rundt omkring i Libanon kommer jæunligt i spil som en instans, der varetager syriske interesser. De libanesiske myndigheder under ministerpræsident Fouad Siniora har det sidste år forsøgt at afvæbne palæstinensiske militser og lukke deres baser, men på det seneste forlyder det, at dette langt fra er lykkedes. Tværtimod er der tegn på, at der i disse måneder foregår såvel en optrapning af konflikterne mellem forskellige grupper inden for lejrene som en fornyet militarisering af grupper i Bekaadalen og på lokaliteter nær de større byer i det vestlige Libanon.

Formentlig kan dette ses som et forsøg på, fra syrisk side, at "spille det palæstinensiske kort" - denne gang i et forsøg på simpelthen at destabilisere situationen i landet, så det bliver vanskeligere at fastholde presset for reformer, herunder presset på præsidenten. Palæstinenserne i Libanon oplever, at de i den nuværende situation, provokeret af den helt umulige situation i forholdet mellem Israel og palæstinenserne i Gaza og på Vestbredden, ikke rigtig har noget at miste og er derfor lette ofre for radikalisering eller blot propaganda om, at de igen kan 
komme til at spille en rolle som i 1970'erne, hvor de var en afgørende politisk magtfaktor i landet og havde stor betydning for forholdet mellem Israel og Syrien.

\section{Syriens dalende indflydelse}

Forholdet mellem Israel og Syrien forekommer permanent særdeles ulige. Israel er i markant grad militært overlegen. I politisk henseende kommer denne ulighed til udtryk ved en stor grad af forskellighed hvad angår udenrigspolitisk handlefrihed. For det første i helt banal militær forstand: Israel har siden årtusindskiftet lagt en hård forsvars- $\mathrm{og}$ udenrigspolitisk linje - tydeligt fx i den israelsk-palæstinensiske konflikt, hvor magten er blevet sat igennem med, hvad der er blevet skønnet nødvendige militære midler med store omkostninger for det palæstinensiske folk. For det andet i relation til den internationale politiske scene, hvor forholdene er vidt forskellige for Israels og Syriens vedkommende. Israel kan gå meget langt uafhængigt af internationale protester, bl.a. fordi USA på grund af krisen i Irak pt. ikke har mulighed for at lægge pres på landet. Syrien er derimod havnet i en situation, hvor man synes ude af stand til at foretage selvstændige udenrigspolitiske skridt.

Den amerikanske administration har siden den 2. Golfkrig, hvor Syrien deltog på den amerikanske lede- de koalitions side mod Saddam Hussein, til dels opretholdt en forestilling om, at Syrien var i en nøgleposition i den mellemøstlige fredsproces og søgte at inddrage Syrien i iscenesættelsen af sin Mellemøstpolitik. Dette har klart været et problem i forhold til den proisraelske dominans i den amerikanske kongres, og denne modsætning er en vigtig del af årsagen til, at bestræbelser fra amerikansk side på at skabe fred mellem Syrien og Israel, har været begrænsede.

Den amerikanske politik i forhold til Syrien har bygget på en interessant kombination af modsætninger og fælles interesser. På den ene side har amerikanerne søgt at kontrollere Syrien gennem lovkomplekser, der har handlet om sikkerhed og våbenkontrol. Desuden har man søgt at påvirke de syriske ledere ved at indføre handelsbegrænsninger. Syrien blev allerede tilbage i 1979 anbragt på den amerikanske liste over stater, der støtter terror. Og anklagen for både at stå bag terrorgrupper og acceptere tilstedeværelsen af bl.a. PFLP i Damaskus har siden fastholdt det spændte forhold.

Men det var ironisk nok netop terrorspørgsmålet, der skabte den tilnærmelse mellem Syrien og den amerikanske administration, som mere eller mindre uafhængigt af det "officielle fjendskab" havde udviklet sig siden begyndelsen af 1990'erne. Ifølge amerikanske kilder var syrerne aktive i frigivelsen af nogle af de 
gidsler, der omkring afslutningen af den libanesiske borgerkrig fortsat sad fast i det libanesiske hængedynd. Det var et paradoks, at samtidig med, at den officielle amerikanske politik, udtrykt i senatets udenrigspolitiske markeringer, bl.a. kritiserede den syriske støtte til Hizbollah, så arbejdede udenrigspolitikkens praktikere i administrationen nok så tæt sammen med Damaskus i forsøg på at løse nogle af de problemer, som terrorgrupperne, herunder Hizbollah, skabte i Libanon.

Der er ingen tvivl om, at Syriens indflydelse i Libanon er for nedadgående. Siden man trak tropperne ud af landet, har man mistet en væsentlig kilde til politiske undertrykkelse af en Syrien-kritisk opposition. At der fortsat er syriske agenter i Libanon, kan næppe diskuteres, men de har i sagens natur ikke mulighed for at operere frit, når de ikke længere i tilspidsede situationer har mulighed for at sætte magt bag forsøg på pression, politiske "initiativer" eller beslutninger om tiltag til støtte for Syrien.

Den ustabile politiske situation i Libanon gør, at der ikke sker fremskridt $\mathrm{i}$ indenrigspolitisk henseende. Og alt andet lige er vedvarende uro og ustabilitet en indirekte støtte til præsident Lahoud, fordi politiske ændringer og reformer kræver ro og sammenhæng i tingene. De kræfter, der støtter Lahoud, har således en vis interesse $i$, at den politiske proces i landet ikke konsolideres.

\section{Hizbollah og Israel}

Hizbollah synes at være forholdsvis tavs i spørgsmålet om Lahoud. Traditionelt har Hizbollah støttet syriske synspunkter, men formentlig er man godt klar over, at det kan være klogt i den aktuelle situation ikke i for høj grad at gøre opmærksom på sig selv, vel vidende at FN-resolution 1559 peger på afvæbning af militser i Libanon, indirekte med adresse til Hizbollah. Ganske vist udtalte Hizbollah-lederen Nasrallah provokerende, i forbindelse med et protestmøde i det sydlige, shiamuslimske Beirut, at hvis USA ville have fat $\mathrm{i}$ modstandsbevægelsens våben, kunne de jo komme og hente dem. Men den slags er retorik, som ingen for alvor tager alvorligt.

For Hizbollah er i stigende omfang blevet "stuerene" og har de sidste år opnået en politisk anseelse i Libanon, der bl.a. bygger på ihærdigt arbejde i forskellige politiske alliancer i parlamentet og i libanesisk lokalpolitik. Den nuværende regering har endda udnævnt et Hizbollah-medlem til minister, energi- og vandminister Muhammad Fneish.

Hizbollah har indtil videre været imod at vælte Lahoud. Dels har Hizbollah tradition for ikke at støtte politiske synspunkter, der er imod syriske interesser, dels er de politiske grupperinger, der arbejder på at vælte Lahoud, ikke populære hos hverken Hizbollahs ledelse eller deres vælgere. Derfor må oppositio- 
nen til Lahoud søge at skabe en situation, hvor grundlaget for at komme af med den upopulære præsident skabes uden om Hizbollah.

Forholdet mellem Israel og Libanon er efter Hizbollah-lederen Hassen Nasrallahs synspunkt en slagmark, og jøderne i Israel er at betragte som moderne korsfarere. De er krigere, der er trængt ind på fjendtligt territorium. Nasrallahs retorik har til formål at retfærdiggøre Hizbollahs angreb på den jødiske besættelsesmagt. Da den amerikanske udsending William Burns i september 2004 besøgte den syriske præsident Bashar al-Assad, forsvarede denne over for Burns Hizbollahs raketangreb mod Israel og erklærede, at de skulle opfattes som en reaktion vendt mod de israelske provokationer i de besatte områder.

De amerikanske udenrigspolitiske repræsentanter på alle niveauer har siden marts 2003, hvor invasionen af Irak blev indledt, haft Damaskus med på rejseplanen i forbindelse med rundrejser i Mellemøsten. Begge parter syntes at have en interesse $i$ at holde hinanden gensidigt orienteret om udviklingen i regionen. En af grundene til dette hænger sammen sammen med det syriske forhold til Libanon og Israel. Assads udtalelse om Hizbollahs bombninger blev tydeligvis formuleret med nogen forsigtighed. På den ene side var det vigtigt for ham at få markeret, at Syrien fortsat havde stor indflydelse på, hvad der skete i Liba- non. På den anden side havde Assad behov for klart at få markeret, at han ikke har noget direkte ansvar for, hvad Hizbollah foretog sig. Derfor var hans udspil denne blanding af den traditionelle uforsonlige antiisraelske retorik og bløde formuleringer om, at man godt kunne forstå Hizbollahs aktioner.

Hizbollah og Israel er fortsat på kollissionskurs. Det har de demonstreret ved utallige lejligheder, og selv om konfliktniveauet synes svingende, forekommer det sandsynligt, at konflikten hurtigt kan optrappes. Syriens udenrigspolitiske position har betydning for situationen i Libanon, men også, om end i begrænset omfang, for både Libanons udenrigspolitiske muligheder - og for Hizbollahs muligheder for at agere.

Der kan stilles spørgsmålstegn ved, om Hizbollah er et reelt problem for Israel. Den kroniske konflikt ved Sheeba Farms har ikke nogen særlig betydning for Israel. Hizbollahs aktioner ved den israelsklibanesiske grænse var et større problem, men overordnet set er Hizbollah ingen trussel for Israel. Derimod kan Hizbollah anvendes i den ideologiske kamp - som en del af den sammenkobling mellem den israelsk-palæstinensiske konflikt og den amerikanske krig mod terror, som de israelske politiske ledere foretager.

På grund af de interne amerikanske modsætninger er det udelukket, at Syrien kan mobilisere USA til at 
lægge pres på Israel. Måske kunne amerikanerne for år tilbage have lagt pres på Israel for at få dem til at gå med til en fred med Syrien - og i den forbindelse give Syrien Golanhøjderne tilbage. Men i 2006 forekommer dette perspektiv ude af trit med virkeligheden, og det er i øvrigt urealistisk, at den nuværende israelske regering vil gå ind i forhandlinger med Syrien om tilbagelevering af Golan. Med mindre der indtræffer store politiske omvæltninger, syntes det sandsynligt, at Golan forbliver på israelske hænder.

I forbindelse med Irak-krisen i forlængelse af den amerikanske invasion i Irak i marts 2003 havde det måske været gunstigt for USA, hvis forholdet mellem Israel og Syrien var bedre, men det har næppe haft nogen afgørende betydning. Libanon spillede i den forbindelse ingen betydningsfuld rolle. Når Syrien blev taget alvorligt af USA, var det af andre årsager. Det handlede om at sikre, at Syrien ikke husede støtter til Saddam Hussein eller på anden vis bidrog til at hjælpe USA's modstandere i konflikten. På et punkt har USA og Syrien fælles interesser, nemlig hvad angår bekæmpelsen af den religiøst begrundede terror.

\section{Det ustabile system og Libanons fremtid}

Den konfessionelle balance, som ligger nedfældet i Libanons forfatning fra 1926 og den nationale pagt fra
1943 og som allerede før borgerkrigen var uretfærdig, er efter årtusindskiftet helt ude af trit med den faktiske virkelighed i Libanon, hvor specielt det meget store shia-muslimske befolkningssegment langt fra har magt, som det har numerisk størrelse. De negative samfundsmæssige og politiske virkninger af Libanons pluralitet er således fastholdt og er vedvarende en kilde til at modvirke skabelsen af national konsensus.

Der syntes som en nærmest permanent tilstand at være en udbredt mangel på tiltro til regeringen i den libanesiske befolkning. Denne mangel på tiltro er et ydre symptom på det grundlæggende problem i den libanesiske virkelighed, den skrøbelige nationale konsensus, som Taifaftalen søgte at skabe. Taif-aftalen bekræftede den religiøst baserede balance, men lagde samtidig op til, at der skulle finde en udvikling sted, som kunne sikre en højere grad af legitimitet.

Det officielle libanesiske system formår imidlertid ikke at tage hul på denne problemstilling. En national konsensus slår ikke for alvor igennem, så længe de sociale og politiske modsætninger afspejler en opsplittet libanesisk realitet, hvor forskellene uddybes snarere end de udlignes - og den fortsatte syriske militære tilstedeværelse er tæt sammenvævet med de politiske modsætninger. På det nationale niveau kommer dette til udtryk i begyndelsen af det nye årtusind i form af en perma- 
nent særdeles ustabil politisk situation.

Et udtryk for dette er, at Libanons præsident Emile Lahoud, der i november 1998 blev indsat af Syriens nu afdøde præsident Hafiz Al-Assad, i det sidste års tid er blevet udsat for et særdeles håndfast, men demokratisk politisk pres, der peger i retning af, at den upopulære præsident må trække sig tilbage.

Præsidenten Emile Lahoud blev indsat den 24. november $1998 \mathrm{i}$ det meget specielle politiske system i Libanon, som fastslår, at præsidenten skal være kristen maronit, ministerpræsidenten sunnimuslim og parlamentsformanden shiamuslim. En præsident vælges for 6 år, men de sidste to præsidenter, dvs. både Lahoud og præsidenten før ham, Elias Hrawi, har fået deres præsidentperiode forlænget med yderligere 3 år. Siden borgerkrigen, der afsluttedes i 1989 har der således været to præsidenter ved magten i landet, Hrawi 1989-1998 og Lahoud, der har fået sin periode forlænget til september 2007.

Der er ikke umiddelbart grundlag for at vælte Lahoud - det libanesiske system er ikke et parlamentarisk system, der sådan kan vælte ministre. Men der kan argumenteres for, at det faktisk aldrig er blevet vedtaget at indsætte Lahoud og at præsidenten således aldrig er blevet genvalgt. Det skal forstås på følgende måde: Den 28. september 2004 vedtog regeringen en tilføjelse til forfatnin- gen, som formelt gav mulighed for at forlænge Lahouds præsidentperiode med tre år. Det var i den forbindelse, at det forlød, at Hariri blev kaldt til Damaskus og fik at vide, at det amerikanske pres på Syrien, situationen i Irak og den kroniske konflikt med Israel gjorde, at forlængelsen af Lahoud var en afgørende syrisk prioritet.

Tre ministre stemte imod vedtagelsen af tilføjelsen til forfatningen og der var omfattende lokale og internationale protester - der i sidste instans førte til vedtagelsen af resolution 1559 i FN. Denne blev vedtaget dagen før der skulle stemmes i Libanons parlament, og afstemningen endte med, at 96 stemte for. Lahouds lokale støtter og pressionen fra Syrien havde stadig i september 2004 stor indflydelse. Der var imidlertid 29, der stemte imod, og ikke mindre end 4 ministre nedlagde deres mandater. Det amerikanske og det franske udenrigsministerium anklagede Syrien for at presse medlemmerne af det libanesiske parlament til at stemme for vedtagelse af tilføjelsen til forfatningen, hvilket utvivlsomt var en korrekt anklage.

Men ifølge den libanesiske forfatning skulle der derefter afholdes en afstemning om indsættelse af Lahoud - og denne blev aldrig afholdt. Det kan derfor med god ret hævdes, at Libanon teknisk set ikke har en præsident. En situation, der ender med at Lahoud må trække sig tilbage, er ikke nødvendigvis identisk 
med at der så er fred og ro. Det modsatte kan meget vel vise sig at være tilfældet. Men under alle omstændigheder kan man sige, at der trods alt er lyspunkter at spore i det politiske opbrud i Libanon. Brede kredse bakker tilsyneladende op om den koalition, der vil af med den syrisk indsatte præsident. Det er sjældent set i den arabiske verdens historie, at en siddende præsident bliver væltet via demokratiske manøvrer. Indsættelsen af Lahoud var helt udemokratisk, forlængelsen af hans præsidentperiode tilsvarende.

I det perspektiv er den nye situation enestående og for så vidt positiv. Men samtidig er der voksende uro i Libanon. Hizbollah står stærkt, der er fornyede problemer i og uden for de palæstinensiske flygtningelejre, der er grupper udefra, måske med tilknytning til terrorgrupper, som opererer i Irak, som gemmer sig i Bekaa-dalen og indebærer intern usikkerhed - og både amerikansk og israelsk overvågning og kontrol. $\mathrm{Og}$ dertil kommer, at det libanesiske parlament er handlingslammet på grund af miséren.

Samtidig hermed foregår der, som man ser det så ofte i forbindelse med politiske kriser, talrige politiske manøvrer i ind- og udland. Flere arabiske ledere har udtalt, at de gerne ser Lahoud udskiftet - dette er også sjældent set i regionen. Det hævdes i mellemøstlige medier, at Mubarak over for Chirac har gjort det samme synspunkt gældende og Lahoud har ved flere lejligheder skarpt kritiseret Chirac for indblanding i indre libanesiske anliggender. Den i Libanon ganske indflydelsesrige kreds af maronitiske biskopper har også samlet udtalt sig skarpt imod præsidenten, og fremtrædende libanesiske ledere fra borgerkrigens tid, Michel Aoun, Samir Geagea m.fl. aktiverer deres kontakter klar til at handle. Man må håbe, det bliver ved de politiske virkemidler.

Peter Seeberg, lektor, ph.d. Centerleder/ studieleder, Center for Mellemøststudier, Syddansk Universitet 